\title{
Analisis Kesulitan Siswa Dalam Menyelesaikan Soal Cerita Fisika Siswa Kelas XI IPA SMA Negeri 1 Tanah Miring Merauke
}

\author{
Ana Wijayanti, I. D. Palittin, Syamsul Bahri \\ ivyalentine@gmail.com \\ Jurusan Pendidikan Fisika, FKIP, Universitas Musamus \\ Jalan Kamizaun, Mopah Lama, Merauke
}

\begin{abstract}
Abstrak - Penelitian ini bertujuan untuk mengetahui faktor penyebab kesulitan yang dialami siswa dalam menyelesaikan soal cerita fisika. Penelitian ini termasuk jenis penelitian kualitatif yang bersifat deskriptif. Subjek penelitian ini adalah siswa kelas XI IPA SMA Negeri 1 Tanah Miring dengan menggunakan teknik purposive sampling untuk mendapatkan 3 siswa dari kategori rendah yang menjadi subjek analisis. Teknik pengumpulan data yang digunakan adalah tes, wawancara dan dokumentasi. Validasi pada penelitian ini digunakan trangulasi sumber dan waktu. Teknik analisis data yang digunakan dalam penelitian ini bersifat deskriptif secara kualitatif, meliputi pengumpulan data, reduksi data, penyajian data dan penarikan kesimpulan. Hasil penelitian sebagai berikut: a) Kesulitan memahami masalah, subjek kurang memahami konsep pada soal sehingga subjek sulit menuliskan informasi yang ada pada soal seperti menuliskan apa yang diketahui dan yang ditanyakan pada soal dengan lengkap. b) Kesulitan merencanakan penyelesaian masalah, kesulitan pada tahap ini subjek mengalami kesulitan seperti subjek lupa rumus, binggung rumus apa yang harus digunakan dalam penyelesaian soal. c) Kesulitan dalam penyelesaian masalah, subjek kesulitan dalam mengaplikasikan apa yang diketahui kedalam persamaan, kesulitan ketika menyelesaikan soal yang membutuhkan perhitungan matematis (seperti perkalian bilangan yang memiliki koma) di karenakan kemampuan berhitung perkalian subjek rendah .d) Kesulitan meninjau kembali masalah, subjek tidak mengecek kembali dan menelaah kembali dengan teliti setiap langkah penyelesaian soal (jawaban), serta tidak mengecek kembali kebenaran dari hasil perhitungan yang telah dikerjakan.
\end{abstract}

Kata Kunci: analisis kesulitan, teori Polya, soal cerita fisika, merauke

\section{PENDAHULUAN}

Fisika merupakan salah satu cabang IImu Pengetahuan Alam (IPA) dan juga menjadi salah satu mata pelajaran yang mengajarkan tentang fakta, konsep, dan prinsip fenomena alam yang terjadi di alam semesta. Kajian dalam bidang ilmu fisika adalah mempelajari tentang materi beserta geraknya dalam ruang dan waktu. Tujuan utama dalam mempelajari fisika adalah mengetahui proses alam bekerja.

Pembelajaran fisika di sekolah diharapkan dapat memberikan pengalaman langsung kepada siswa tentang alam semesta secara ilmiah [1]. Fisika yang mempelajari fenomena alam yang terjadi dalam kehidupan sehari-hari, sebenarnya telah dipelajari secara tidak langsung oleh siswa melalui pengalaman sehari-hari. Hal ini membentuk pemikiranpemikiran siswa tentang konsep fisika terkait dengan peristiwa alam yang terjadi. Pembentukan konsep fisika ini sesuai dengan pernyataan Osman dan Sukor, yaitu "Theoritically student conceptions are built from their interactions with other people or learning mediums" [2].
Fisika yang merupakan salah satu ilmu penting dianggap juga sebagai salah satu mata pelajaran paling sulit untuk dipahami. Bagi sebagian besar siswa, fisika dianggap rumit dan sulit untuk dipahami karena pembelajarannya lebih banyak menekankan pada rumus-rumus, tanpa ada penjabaran mengenai pentingnya rumus tersebut dan aplikasinya dalam kehidupan sehari-hari. Hal inilah yang membuat siswa menjadi malas dan juga nilai fisika mereka tidak memuaskan.

Kesulitan siswa dalam pelajaran fisika yaitu pada saat mereka menyelesaikan soal dalam bentuk cerita. Mereka sulit untuk memahami maksud dari soal cerita tersebut. Hal inilah yang membuat mereka tidak tau cara untuk menyelesaikan soal cerita dalam ujian. Kesulitan-kesulitan inilah yang perlu dianalisis sehingga dapat diperoleh solusi untuk permasalahan ini. Salah satu teori yang dapat digunakan adalah teori Polya, yaitu teori yang menggunakan langkah-langkah tertentu dalam memecahkan suatu masalah fisika [3].

Rumusan masalah dari permasalahan di atas yaitu, kesulitan siswa dalam menyelesaikan soal fisika dalam bentuk cerita. Tujuan dari penelitian ini adalah untuk mengetahui 
kesulitan yang dialami siswa dalam menyelesaikan soal cerita fisika pada materi gerak dengan analisis vektor di kelas XI IPA SMA Negeri 1 Tanah Miring. Fokus penelitian in adalah kesulitan siswa dalam menyelesaikan soal cerita fisika dilihat dari minat dan pemahaman siswa

\section{A. Pembelajaran Fisika}

Proses pembelajaran yang dilakukan di sekolah memiliki tujuan untuk peserta didik. Selama proses pembelajaran berlangsung, siswa diharuskan untuk mengingat, mengaitkan, dan memperhatikan guru dan juga pelajaran [1]. Dalyono mengungkapkan bahwa tujuan belajar adalah: mengadakan perubahan tingkah laku, merubah kebiasaan buruk menjadi kebiasaan baik, memiliki ketrampilan, dan juga menambah pengetahuan dalam berbagai bidang ilmu [4].

Setiap mata pelajaran memiliki tujuannya masing-masing, begitupun dengan pembelajaran fisika. Menurut Bloom, tujuan pembelajaran fisika adalah dapat memberikan pengetahuan (kognitif) berupa prinsip dan konsep fisika yang bermanfaat untuk kehidupan sehari-hari [1]. Selain kognitif, diharapkan juga dapat memberikan dan meningkatkan ketrampilan proses (psikomotorik) dan juga kemampuan sikap (afektif) dalam menyelesaikan suatu permasalahan [5]. Proses pembelajaran fisika seharusnya mengikuti langkah-langkah ilmah mulai dari perumusan masalah, penyusunan hipotesis, pengujian hipotesis melalui eksperimen, hingga penarikan kesimpulan [5].

\section{B. Kesulitan Belajar Fisika}

Setiap proses pembelajaran, pasti mengalami kesulitan, baik dari siswa sebagai peserta didik maupuan guru sebagai pengajar. Kesulitan belajar merupakan kondisi belajar yang berjalan tidak semestinya karena adanya hambatan-hambatan untuk mencapai hasil belajar [6]. Kesulitan belajar yang dialami oleh seorang siswa dapat mempengaruhi hasil belajarnya, yaitu hasil belajar yang diperoleh tidak sesuai dengan harapan. [4].

Kesulitan belajar yang dialami oleh siswa, dipengaruhi oleh dua faktor yaitu faktor dari dalam diri siswa (internal) dan faktor dari luar diri siswa (eksternal). Menurut Syah, faktor internal berkaitan dengan kekurangmampuan secara psikologi maupun fisik dari seorang siswa, yaitu bersifat kognitif yang berhubungan dengan proses psikologis dan kemampuan mental, bersifat afektif yang berhubungan dengan labilnya emosi dan sikap, dan bersifat psikomotorik yang berhubungan dengan terganggunya indera penglihatan dan pendengaran [7].

Faktor eksternal yang mempengaruhi kesulitan belajar siswa adalah lingkungan keluarga yang berhubungan dengan keharmonisan antar anggota keluarga dan kehidupan ekonomi keluarga; lingkungan masyarakat yang berhubungan dengan wilayah tempat tinggal dan teman sepermainan; lingkungan sekolah yang berhubungan dengan kondisi sekolah, guru, dan ketersediaan fasilitas pendukung proses pembelajaran [7]. Faktorfaktor tersebut dapat mempengaruhi siswa dalam proses belajar, baik itu pada saat pembelajaran berlangsung ataupun pada saat siswa menyelesaikan permasalahan.

Kesulitan belajar yang dialami oleh siswa dalam pembelajaran fisika banyak ditemui pada saat siswa menyelesaikan suatu soal cerita. Penelitian yang dilakukan oleh Ira dan Yuliana, kesulitan belajar siswa kelas X SMA tentang materi listrik dinamis adalah mendeskripsikan arus searah dan arus bolak balik, penentuan grafik hubungan antara arus dan tegangan, penentuan arus masuk dan keluar dalam hukum Kirchoff, dan juga konversi satuan [8].

Penelitian yang dilakukan oleh Meizufan dkk, yaitu penelitian tentang kesulitan belajar fisika yang dialami oleh siswa RSMABI di Semarang, diperoleh bahwa siswa mengalami kesulitan dalam hal penguasaan konsep [9]. Adapun faktor yang mempengaruhinya adalah minat, bakat, motivasi, intelegensi, fasilitas sekolah, dan juga guru.

\section{Pemecahan Masalah Fisika Menurut Teori Polya}

Penyelesaian masalah kesulitan yang dialami siswa memerlukan langkah-langkah secara sistematis dan berstruktur agar penyelesaiannya mudah dan terarah. Penyelesaian masalah kesulitan yang dialami siswa dapat dilakukan berdasarkan teori Polya. Melalui teori Polya ini lebih memudahkan untuk mengetahui tingkat kesulitan siswa dalam mnyelesaikan soal cerita fisika.

Teori Polya menerapkan langkah-langkah penyelesaian masalah secara sistematis yang bertujuan untuk meyakinkan konsep-konsep yang telah dipelajari [3]. Adapun langkah penyelesaian masalah fisika berdasarkan teori Polya dapat dilihat pada Gambar 1 berikut: 


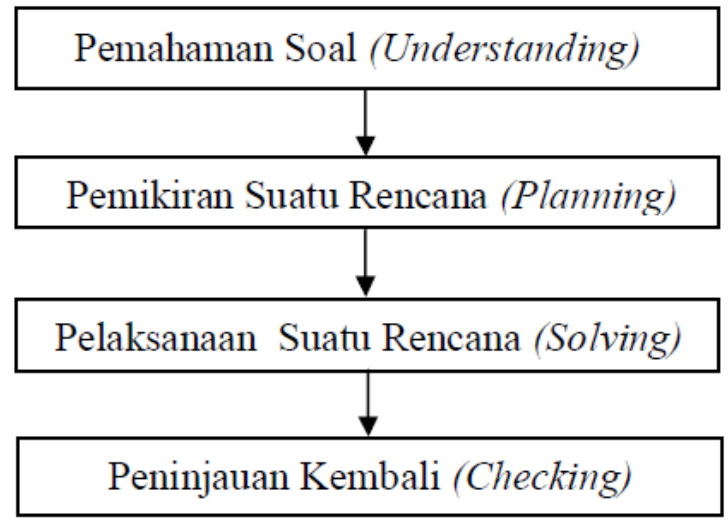

Gbr 1. Penyelesaian Masalah Fisika Berdasarkan Teori Polya (modifikasi dari [10])

Langkah pertama, yaitu pemahaman soal yang dimaksud adalah siswa harus dapat memahami maksud dan masalah yang ada pada soal. Langkah kedua, pemikiran suatu rencana, siswa diharuskan mencari konsep atau teori yang berhubungan dengan soal tersebut. Pada langkah ini, siswa juga diharuskan untuk memikirkan solusi yang tepat untuk menyelesaikan soal.

Langkah ketiga, siswa melakukan perhitungan secara sistematis sesuai dengan teori, konsep dan rumus yang telah disiapkan. Langkah terakhir, siswa menelaah kembali jawaban yang telah dibuat dan juga sistematika penyelesaian masalah pada soal tersebut.

\section{METODOLOGI PENELITIAN}

Penelitian ini merupakan penelitian kualitatif yang bersifat deskriptif, yaitu penelitian yang menggambarkan keadaan kesulitan siswa dalam menyelesaikan soal cerita. Penelitian dilaksanakan di SMA Negeri 1 Tanah Miring, Kabupaten Merauke, Papua. Subjek penelitian adalah siswa kelas XI IPA SMA Negeri 1 Tanah Miring.

Teknik pengambilan sampel menggunakan teknik purposive sampling dengan tujuan untuk mendapatkan 3 siswa dengan kategori rendah. Pengambilan sampel dilakukan dengan cara memberikan tes diagnostic kepada seluruh siswa kelas XI IPA SMA Negeri 1 Tanah Miring. Adapun soal yang diberikan adalah soal dalam bentuk cerita berjumlah 8 soal dengan materi vektor. Pembagian kategori untuk siswa menggunakan rumus standar deviasi sebagai berikut:

$$
S D=\sqrt{\frac{\sum x^{2}}{n}-\left(\frac{\sum x}{n}\right)^{2}}
$$

Keterangan:

$S D$ : standar deviasi

$x$ : nilai siswa

$n$ : jumlah siswa

Penggolongan tiga kategori siswa disesuiakan dengan Tabel 1 berikut [11]:

TABEL 1 PENGGOLONGAN KATEGORI KEMAMPUAN SISWA

\begin{tabular}{ll}
\hline Rentang Nilai & Kategori \\
\hline Nilai $>\bar{x}+$ SD & Tinggi \\
\hline $\bar{x}-$ SD $<$ Nilai $<\bar{x}+$ SD & Sedang \\
\hline Nilai $<\bar{x}-$ SD & Rendah \\
\hline
\end{tabular}

Tahap selanjutnya ketiga subjek kategori rendah dilakukan tahap pengerjaan soal analisis yang terdiri dari 3 soal uraian dan wawancara. Tes analisis dilakukan bersamaan dengan mewawancarai subjek agar mengetahui kesulitan apa saja yang dialami siswa dalam menyelesaikan soal fisika dalam bentuk cerita.

Uji keabsahan untuk mengurangi subyektifitas data yang diperoleh maka dilakukan triangulasi teknik dan triangulasi waktu. Deskripsi pertama kesulitan yang dialami siswa dalam menyelesaikan soal cerita fisika berdasarkan kesulitan yang dialami saat menyelesaikan soal analisis dengan teori Polya dan deskripsi kedua yaitu analisis hasil transkip wawancara untuk mengetahui kesulitan yang dialamai siswa dalam menyelesaikan soal cerita fisika.

\section{HASIL DAN PEMBAHASAN}

Pengambilan data dilakukan dari 3 siswa dengan kategori rendah. Pemeriksaan soal tes diagnostic dari 24 siswa, diperoleh pengelompokkan kemampuan siswa, yaitu (1)siswa dengan kategori tinggi sebanyak 4 responden; (2)siswa dengan kategori sedang sebanyak 16 responden; dan siswa dengan kategori rendah sebanyak 4 responden. Sebanyak 3 siswa dari kategori rendah diambil untuk diberikan tes analisis dan wawancara.

Dari ketiga subjek yang telah diberi tes analisis dan diwawancarai, didapatkan kesulitan siswa dalam menyelesaikan soal cerita fisikadi lihat dari pemecahan soal teori Polya sebagai berkut: 
TABEL 2 KESULITAN SISWA UNTUK SOAL NOMOR 1

\begin{tabular}{|c|c|c|c|}
\hline \multirow{2}{*}{$\begin{array}{c}\text { Jenis } \\
\text { Kesulitan }\end{array}$} & \multicolumn{3}{|c|}{ Letak Kesulitan Nomor 1} \\
\hline & $\begin{array}{c}\text { Subjek } \\
\text { Rendah } 1\end{array}$ & $\begin{array}{c}\text { Subjek } \\
\text { Rendah } 2\end{array}$ & $\begin{array}{c}\text { Subjek } \\
\text { Rendah } 3\end{array}$ \\
\hline $\begin{array}{l}\text { Pemah } \\
\text { aman } \\
\text { soal }\end{array}$ & $\begin{array}{l}\text { Tidak } \\
\text { mengalami } \\
\text { kesulitan }\end{array}$ & $\begin{array}{l}\text { Tidak } \\
\text { memahami } \\
\text { soal dengan } \\
\text { baik }\end{array}$ & $\begin{array}{l}\text { Tidak } \\
\text { memahami } \\
\text { soal dengan } \\
\text { baik }\end{array}$ \\
\hline $\begin{array}{l}\text { Pemikir } \\
\text { an } \\
\text { suatu } \\
\text { rencan } \\
\text { a }\end{array}$ & $\begin{array}{l}\text { Salah } \\
\text { menggunaka } \\
\text { n simbol } a_{1}, \\
b_{1}, \text { dan } a_{2}, b_{2} \\
\text { pada apa } \\
\text { yang } \\
\text { diketahui }\end{array}$ & $\begin{array}{l}\text { Salah } \\
\text { menggunakan } \\
\text { simbol } a_{1}, b_{1}, \\
\text { dan } a_{2}, b_{2} \\
\text { pada apa } \\
\text { yang } \\
\text { diketahui. }\end{array}$ & $\begin{array}{l}\text { Salah } \\
\text { menggunaka } \\
\text { n simbol } a_{1}, \\
b_{1}, \text { dan } a_{2}, b_{2} \\
\text { pada apa } \\
\text { yang } \\
\text { diketahui. }\end{array}$ \\
\hline $\begin{array}{l}\text { Pelaksa } \\
\text { naan } \\
\text { suatu } \\
\text { rencan } \\
\text { a }\end{array}$ & $\begin{array}{l}\text { Tidak } \\
\text { mengalami } \\
\text { kesulitan }\end{array}$ & $\begin{array}{l}\text { Salah pada } \\
\text { langkah- } \\
\text { langkah } \\
\text { persamaan } \\
\text { rumus } \Delta r . \\
\text { Dan } \\
\text { menyimpulkan } \\
\text { hasil akhirnya. }\end{array}$ & $\begin{array}{l}\text { Salah pada } \\
\text { langkah- } \\
\text { langkah } \\
\text { persamaan } \\
\text { rumus } \Delta r . \\
\text { Dan } \\
\text { menyimpulk } \\
\text { an hasil } \\
\text { akhirnya }\end{array}$ \\
\hline $\begin{array}{l}\text { Peninja } \\
\text { uan } \\
\text { kembali }\end{array}$ & $\begin{array}{l}\text { Tidak } \\
\text { menuliskan } \\
\text { hasil dengan } \\
\text { satuannya }\end{array}$ & $\begin{array}{l}\text { Tidak } \\
\text { meninjau } \\
\text { kembali } \\
\text { jawaban yang } \\
\text { diperoleh }\end{array}$ & $\begin{array}{l}\text { Tidak } \\
\text { meninjau } \\
\text { kembali } \\
\text { jawaban } \\
\text { yang } \\
\text { diperoleh }\end{array}$ \\
\hline
\end{tabular}

Lembar jawaban SR01 diketahui bahwa subjek kurang memahami soal dengan baik tetapi dari langkah-langkah apa yang diketahui simbol pada lembar jawaban menggunakan simbol posisi $a_{1}, b_{1}$, dan $a_{2}, b_{2}$ seharusnya menggunakan simbol $\overrightarrow{r_{1}}$ dan $\overrightarrow{r_{2}}$. Penggunaan rumus arah perpindahan pesawat sudah benar, tetapi simbol dalam pengurangan posisi yang akan diakarkan menggunakan simbol yang salah.

Lembar jawaban SR02 diketahui bahwa subjek kurang memahami soal dengan baik, tetapi dari langkah-langkah apa yang diketahui simbol pada lembar jawaban menggunakan simbol posisi $a_{1}, b_{1}$, dan $a_{2}, b_{2}$ seharusnya menggunakan simbol $\overrightarrow{r_{1}}$ dan $\overrightarrow{r_{2}}$. Akan tetapi pada penulisan apa yang ditanya, siswa menggunakan simbol $\Delta r$ dan seharusnya $\overrightarrow{\Delta r}$. Tahap merencanakan permasalahan, dalam soal ditanyakan besar perpindahan yang dialami pesawat. Dalam penggunakan rumus arah perpindahan pesawat sudah benar, tetapi langkah-langkah mendapatkan $\Delta r$ salah, seharusnya $\overrightarrow{r_{1}}-\overrightarrow{r_{2}} \quad$ kemudian hasilnya dimasukkan kedalam bentuk akar. Siswa SR02 menuliskan langkah-langkahnya yaitu di cari $\overrightarrow{\Delta r_{1}}$ terlebih dahulu lalu dicari $\overrightarrow{\Delta r_{2}}$. Pelaksanaan rencana SR02 melakukan kesalahan, maka hasil yang diperoleh juga salah tetapi satuan yang digunakan benar. Subjek SR03 didapatkan letak kesulitan yang dialami sama dengan subjek SR02.

TABEL 3 KESULITAN SISWA UNTUK SOAL NOMOR 2

\begin{tabular}{|c|c|c|c|}
\hline \multirow[b]{2}{*}{$\begin{array}{c}\text { Jenis } \\
\text { Kesulitan }\end{array}$} & \multicolumn{3}{|c|}{ Letak Kesulitan Nomor 2} \\
\hline & $\begin{array}{c}\text { Subjek } \\
\text { Rendah } 1\end{array}$ & $\begin{array}{c}\text { Subjek } \\
\text { Rendah } 2\end{array}$ & $\begin{array}{c}\text { Subjek } \\
\text { Rendah } 3\end{array}$ \\
\hline $\begin{array}{l}\text { Pemahaman } \\
\text { soal }\end{array}$ & $\begin{array}{l}\text { Tidak } \\
\text { mengalami } \\
\text { kesulitan }\end{array}$ & $\begin{array}{l}\text { Tidak } \\
\text { mengalami } \\
\text { kesulitan }\end{array}$ & $\begin{array}{l}\text { Tidak } \\
\text { mengalami } \\
\text { kesulitan }\end{array}$ \\
\hline $\begin{array}{l}\text { Pemikiran } \\
\text { suatu } \\
\text { rencana }\end{array}$ & $\begin{array}{l}\text { Salah } \\
\text { simbol } \\
\text { yang } \\
\text { digunakan }\end{array}$ & $\begin{array}{l}\text { Tidak } \\
\text { mengalami } \\
\text { kesulitan }\end{array}$ & $\begin{array}{l}\text { Tidak } \\
\text { mengalami } \\
\text { kesulitan }\end{array}$ \\
\hline $\begin{array}{l}\text { Pelaksanaan } \\
\text { suatu } \\
\text { rencana }\end{array}$ & $\begin{array}{l}\text { Tidak } \\
\text { mengalami } \\
\text { kesulitan }\end{array}$ & $\begin{array}{l}\text { Salah tidak } \\
\text { menggunakan } \\
\text { satuan pada } \\
\text { langkah- } \\
\text { langkah } \\
\text { penyelesaiann } \\
\text { ya }\end{array}$ & $\begin{array}{l}\text { Tidak } \\
\text { mengalami } \\
\text { kesulitan }\end{array}$ \\
\hline $\begin{array}{l}\text { Peninjauan } \\
\text { kembali }\end{array}$ & $\begin{array}{l}\text { Tidak } \\
\text { mengalami } \\
\text { kesulitan }\end{array}$ & $\begin{array}{l}\text { Tidak } \\
\text { meninjau } \\
\text { kembali } \\
\text { jawban yang } \\
\text { diperoleh }\end{array}$ & $\begin{array}{l}\text { Tidak } \\
\text { mengalami } \\
\text { kesulitan }\end{array}$ \\
\hline
\end{tabular}

Lembar jawaban SR01 diketahui bahwa subjek telah memahami soal dengan baik, terlihat pada pemahaman soal dan pemikiran suatu rencana siswa telah memahaminya. SR01 menuliskan langkah-langkah apa yang diketahui tidak mengalami kesulitan. Akan tetapi pada penulisan apa yang ditanyakan siswa salah dalam menuliskan pensimbolannya, dikarenakan siswa kurang paham apa yang ditanyakan pada soal. Kemudian pada tahap pelaksanaan rencana SR01 tidak mengalami kesulitan apapun.

Lembar jawaban SR02 diketahui bahwa subjek telah memahami soal dengan baik, pemahaman soal dan pemikiran suatu rencana siswa telah memahaminya. SR02 menuliskan langkah-langkah apa yang diketahui tidak mengalami kesulitan dan dalam penulisan apa yang ditanyakan siswa tidak mengalami kesulitan, akan tetapi dalam langkah-langkah penyelesaiannya ketika SR02 mencari waktu yang digunakan karena pada soal belum diketahui waktunya, siswa tidak menuliskan satuannya pada hasil. Kemudian pada tahap pelaksanaan rencana SR02 tidak mengalami kesulitan apapun.

Sedangkan pada subjek SR03 letak kesulitan yang dialami oleh respond sama dengan subjek SR02. 
TABEL 4 KESULITAN SISWA UNTUK SOAL NOMOR 3

\begin{tabular}{|c|c|c|c|}
\hline \multirow[b]{2}{*}{$\begin{array}{c}\text { Jenis } \\
\text { Kesulitan }\end{array}$} & \multicolumn{3}{|c|}{ Letak Kesulitan Nomor 3} \\
\hline & $\begin{array}{c}\text { Subjek } \\
\text { Rendah } 1\end{array}$ & $\begin{array}{c}\text { Subjek } \\
\text { Rendah } 2\end{array}$ & $\begin{array}{c}\text { Subjek } \\
\text { Rendah } 3\end{array}$ \\
\hline $\begin{array}{l}\text { Pemahama } \\
\text { n soal }\end{array}$ & $\begin{array}{l}\text { Salah tidak } \\
\text { menuliskan } \\
\text { satuan dan } \\
\text { apa yang } \\
\text { diketahui }\end{array}$ & $\begin{array}{l}\text { Salah tidak } \\
\text { menuliskan } \\
\text { satuan } \\
\text { pada apa } \\
\text { yang } \\
\text { diketahui }\end{array}$ & $\begin{array}{l}\text { Salah tidak } \\
\text { menuliskan } \\
\text { satuan pada } \\
\text { apa yang } \\
\text { diketahui }\end{array}$ \\
\hline $\begin{array}{l}\text { Pemikiran } \\
\text { suatu } \\
\text { rencana }\end{array}$ & $\begin{array}{l}\text { Tidak } \\
\text { mengalami } \\
\text { kesulitan }\end{array}$ & $\begin{array}{l}\text { Tidak } \\
\text { mengalami } \\
\text { kesulitan }\end{array}$ & $\begin{array}{l}\text { Tidak } \\
\text { mengalami } \\
\text { kesulitan }\end{array}$ \\
\hline $\begin{array}{l}\text { Pelaksanaa } \\
\text { n suatu } \\
\text { rencana }\end{array}$ & $\begin{array}{l}\text { Salah } \\
\text { diperhitunga } \\
\text { n dalam } \\
\text { persamaan }\end{array}$ & $\begin{array}{l}\text { Tidak } \\
\text { mengalami } \\
\text { kesulitan }\end{array}$ & $\begin{array}{l}\text { Tidak } \\
\text { mengalami } \\
\text { kesulitan }\end{array}$ \\
\hline $\begin{array}{l}\text { Peninjauan } \\
\text { kembali }\end{array}$ & $\begin{array}{l}\text { Tidak } \\
\text { menuliskan } \\
\text { satuan }\end{array}$ & $\begin{array}{l}\text { Salah pada } \\
\text { hasil akhir } \\
\text { tidak } \\
\text { dituliskan } \\
\text { satuannya }\end{array}$ & $\begin{array}{l}\text { Tidak } \\
\text { mengalami } \\
\text { kesulitan }\end{array}$ \\
\hline
\end{tabular}

Lembar jawaban SR01 pada soal nomor 3 diketahui bahwa subjek kurang memahami soal dengan baik, pemahaman soal dan pemikiran suatu rencana siswa belum memahaminya. SR01 menuliskan langkah-langkah apa yang diketahui mengalami kesulitan karena tidak dituiskan satuannya. Pada penulisan apa yang ditanyakan siswa tidak menuliskan pensimbolannya, dikarenakan siswa kurang paham dan lupa apa yang ditanyakan pada soal. Kemudian pada tahap pelaksanaan rencana SR01 tidak mengalami kesulitan apapun. Akan tetapi pada tahap memasukan apa yang diketahui ke persamaan, siswa mengalami kesulitan dalam perkalian dan kesulitan dalam merubah $0,5 \mathrm{~cm}$ menjadi jarijari. Dengan kesalahan dalam mengalikan kedalam persamaan, maka hasil akhir yang didapat SR01 salah dan siswa tidak menuliskan satuannya.

Lembar jawaban SR02 pada soal nomor 3 diketahui bahwa subjek kurang memahami soal dengan baik, pemahaman soal dan pemikiran suatu rencana siswa belum memahaminya. SR02 menuliskan langkah-langkah apa yang diketahui mengalami kesulitan karena tidak dituiskan satuannya. Pada penulisan apa yang ditanyakan siswa tidak mengalami kesulitan pensimbolannya. Kemudian pada tahap pelaksanaan rencana SR02 tidak mengalami kesulitan apapun. Siswa dapat menyelesaiakn persamaan dengan baik, maka hasil akhir yang didapat SR02 benar tetapi tidak dituliskan satuannya.

Lembar jawaban SR03 pada soal nomor 3 diketahui bahwa subjek kurang memahami soal dengan baik., pemahaman soal dan pemikiran suatu rencana siswa belum memahaminya.
SR03 menuliskan langkah-langkah apa yang diketahui mengalami kesulitan karena tidak dituiskan satuannya. Pada penulisan apa yang ditanyakan siswa tidak mengalami kesulitan persimbolannya. Kemudian pada tahap pelaksanaan rencana SR03 tidak mengalami kesulitan apapun. Siswa dapat menyelesaiakan persamaan dengan baik, maka hasil akhir yang didapat SR03 benar dengan satuannya

\section{KESIMPULAN}

Hasil analisis data terhadap hasil tes soal bentuk uraian pada pokok materi gerak dengan analisis vektor dapat disimpulkan bahwa a) Kesulitan memahami masalah, subjek kurang memahami konsep pada soal sehingga subjek sulit menuliskan informasi yang ada pada soal seperti menuliskan apa yang diketahui dan yang ditanyakan pada soal dengan lengkap. b) Kesulitan merencanakan penyelesaian masalah, kesulitan pada tahap ini subjek mengalami kesulitan seperti subjek lupa rumus, binggung rumus apa yang harus digunakan dalam penyelesaian soal. c) Kesulitan dalam penyelesaian masalah, subjek kesulitan dalam mengaplikasikan apa yang diketahui kedalam persamaan, kesulitan ketika menyelesaikan soal yang membutuhkan perhitungan matematis (seperti perkalian bilangan yang memiliki koma) di karenakan kemampuan berhitung perkalian subjek rendah .d) Kesulitan meninjau kembali masalah, subjek tidak mengecek kembali dan menelaah kembali dengan teliti setiap langkah penyelesaian soal (jawaban), serta tidak mengecek kembali kebenaran dari hasil perhitungan yang telah dikerjakan.

\section{DAFTAR PUSTAKA}

[1] K. S. Kallesta and M. Erfan, "Analisis Faktor Penyebab Kesulitan Belajar IPA Fisika pada Materi Bunyi". Junal Pendidikan Fisika Volume 1 No 1, September 2017.

[2] K. Osman, "Conceptual Understanding in Secondary School Chemistry: A Discussion". Jurnal Pendidikan Fisika Volume 2, No. 2, p. 19, 2014.

[3] Musdalifah, "Analisis Kesulitan Siswa dalam Menyelesaikan Soal-Soal Fisika pada Materi Kalor Berdasarkan Teori Polya di Kelas X SMA N 2 Teluk Dalam," Universitas Islam Negeri Ar-Raniry Darussalam Banda Aceh, 2017.

[4] M. Dalyono, Psikologi Pendidikan. Jakarta: Rineka Cipta, 2009.

[5] Trianto, Model Pembelajaran Terpadu. Jakarta: Bumi Aksara, 2010.

[6] Abbas dan M. Y. Hidayat, "Faktor-Faktor Kesulitan Belajar Fisika Pada Peserta Didik,". Jurnal Pendidikan Fisika Volume 6, No. 1, pp. 45-49, 2018.

[7] M. Syah, Psikologi Pendidikan dengan Pendekatan Baru. Bandung: PT. Remaja Rosdakarya, 2002.

[8] Ira Nofitasari dan Yuliana Sihombing. "Deskripsi 
Kesulitan Belajar Peserta Didik dan Faktor Penyebabnya dalam Memahami Materi Listrik Dinamis Kelas X SMA Negeri 2 Bengkayang". Jurnal Penelitian Fisika dan Aplikasinya (JPFA). Volume 7, No. 1, pp. 44-53, 2017.

[9] M. K. Arief, L. Handayani, dan P. Dwijananti, "Identifikasi Kesulitan Belajar Fisika Pada Siswa Rsbi :
Studi Kasus Di Rsmabi Se Kota Semarang". Unnes Physics Education Journal. Volume 1, No. 2, pp. 5-10, 2012.

[10] G. Polya, How To Solve IT. USA: Stanford University, 1957.

[11] S. Arikunto, Dasar-Dasar Evaluasi Pendidikan Edisi 2. Jakarta: Bumi Aksara, 2012. 